\title{
Teaching to the curriculum or teaching to the test
}

\author{
Roseline Sama ${ }^{1}$, Jeneth Yemisi Adegbuyi ${ }^{2}$, Mercy Ifunanya Ani ${ }^{3}$ \\ Institute of Education, University of Ibadan, Nigeria ${ }^{1,2}$ \\ Alex Ekweme Federal University, Ndufu Alike, Ebonyi State, Nigeria ${ }^{3}$ \\ anochiwar@yahoo.com ${ }^{1}$, yemisiadegbuyi@yahoo.com ${ }^{2}$, merciful.ssit@yahoo.com ${ }^{3}$
}

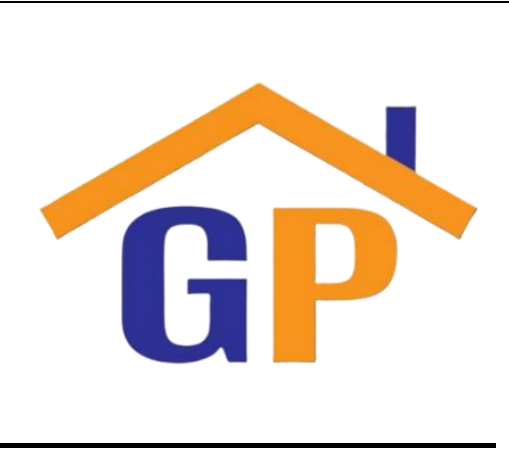

Article History

Received on 19 December 2020

$1^{\text {st }}$ Revision on 14 January 2021

$2^{\text {nd }}$ Revision on 23 January 2021

Accepted on 25 January 2021

\section{Abstract}

Purpose: This research aimed to investigate teaching practices that dominates the West African Senior Secondary Certificate Examination class to ascertain discrepancies between the prescribed and implemented curriculum.

Research methodology: The study adopted ex-post facto research design of a survey type. 1719 students and 53 mathematics teachers participated in the study. Four instruments were used for data collection: Mathematics Content Completion Inventory, Teaching Depth Rating Scale( $\mathrm{r}=0.96)$, Classroom Observation Checklist $(\mathrm{r}=0.95)$ and Mathematics Learning Task( $\mathrm{r}=0.95)$. Data were analyzed using descriptive statistical model in SPSS version 20.

Results: Results indicated that Full implementation of the prescribed curriculum ranged between $46.2 \%$ to $86.5 \%$ for 54 topics, but only three out of them were indepthly taught. Teaching activities revolved around examination preparation, with the highest percentage of 48.55 among nine different categories.

Limitation: This study was limited to only one state in Nigeria, one subject and one type of high-stakes examination. It can be replicated on different school subjects to provide greater generalizability.

Contribution: Results will help stakeholders strategise on reforms that will promote in-depth teaching and optimal implementation of the prescribed mathematics curriculum.

Keywords: Curriculum, High-Stakes examination, Mathematics, Teaching depth

How to cite: Sama, R., Adegbuyi, J. Y., \& Ani, M. I. (2021). Teaching to the curriculum or teaching to the test. Journal of Social, Humanity, and Education, 1(2), 103-116.

\section{Introduction}

Curriculum is an instrument through which educational institutions translate societal values into actual reality and consequently achieve the desired learning outcome. Also, curriculum can be seen as a systematic reconstruction of knowledge and experience with the guidance of the school and relevant agencies, enabling the learner to have a better mastery of learning experiences for the learner and society's well-being. Curriculum reforms have been on from the pre-colonial time to the present day and a significant aspect of these reforms is the Mathematics curriculum which has passed through so many developmental changes.

As part of the reformation agenda, the Nigerian Educational Research and Development Council, NERDC was directed in 2005 by the National Council on Education (NCE) to review the existing senior secondary school curricula to meet the target of the reform in the context of National Economic Empowerment and Development Strategies (NEEDS) and the Millennium Development Goal. The targets were; poverty eradication, job creation, value orientation, wealth generation and empowerment through education. Hence it became necessary to review the existing secondary school curriculum. It 
was against this background that the secondary school Mathematics curriculum had some topics added to the existing ones. This includes some introductory topics in matrices, modular arithmetic, simple calculus (differentiation and integration), simple co-ordinate geometry, logical reasoning, financial mathematics like annuity and amortization and aims at imparting knowledge and skills and using examination to assess the level of mastery of the acquired knowledge and skills (Azuka, B.; Jekayinfa, O.; Durojaiye, D.; Okwuoza, S. 2013)

Regrettably, due to the importance accorded examinations, aims of the curriculum seem to be weakened or defeated even though they are clearly spelt out in the prescribed curriculum documents. Teachers see the kind of intellectual activity required by previous examination questions and prepare the students to meet these demands. Hence the implemented curriculum appears to be driven by the examined curriculum. Teachers who are experienced in teaching examination classes study the examination pattern, identify content areas that are usually covered in previous examination and predict with great precision areas that may likely be examined in future examination. As a result, they may concentrate on teaching those areas at the expense of the whole prescribed curriculum content to the detriment of the learner. Tugba (2012), Shiva E. (2012), Kelleghan et al. (1996), Enwefa Chiekem (2014), Amengual (2009).

This implies that high-stakes examinations motivate teachers and students to work towards performance goals rather than learning goals. According to Linn (2000), the increase in scores, especially in high-stakes examination context, most likely indicates teachers and students' familiarity with examination requirements and formats rather than the real improvement in learning. Saye (2013) criticized high-stakes testing for restricting teachers' efforts to incorporate authentic instruction in schools and believed that such assessments are generally limited to lower-level content knowledge and encourage narrowing the curriculum rather than in-depth content knowledge and active learning. Teachers and administrators may also not adopt inquiry-based and active teaching approaches in a high-stakes setting for fear. They will negatively impact student performance in examinations Kulamakan and Patangi (2018).

Mathematics has been a major area of investigation as a core curriculum subject and a content of almost all tests, given nationally and internationally. According to the UNESCO Report (2015 p.191), national assessments are predominantly curriculum-based and subject-oriented and $98 \%$ of these assessments cover Mathematics. Its value goes beyond the classroom and the school; therefore, it must be learned comprehensively and with much depth as a school subject. Its twin goals are the development of students' critical thinking and problem-solving skills, which could be achieved through an organized and rigorous curriculum content, a well-defined set of high-level skills and processes, desirable values, attitudes, and appropriate tools (Sabio, J., Balagtas, M., and David, D. 2015). This cannot be achieved through surface teaching. Are we testing for teaching or teaching for testing?

When a teacher teaches to the test, it will lead to surface learning, narrowing of the curriculum, surface teaching and performance goal orientation. On the other hand, teaching to the curriculum will lead to in-depth teaching and learning, learning goal orientation, active learning and full implementation of curriculum content. Also, instructional content will align with curriculum content. However, it is unclear what kind of teaching practices dominate the certificate class in Nigerian secondary schools. This is a major gap in literature and motivation for this study.

\section{Research Question}

1. What level of discrepancies exists between the Senior Secondary Certificate Mathematics Curriculum content in Nigeria and what teachers teach?

2. What kind of teaching practices dominates the Senior Secondary Certificate Mathematics class?

3. What is the depth of Mathematics teaching at the certificate exit class?

\section{Literature review and hypotheses development}

Testing is given in schools for ten potential benefits besides its traditional function of assigning grades and certification (Roediger, Outnam and Smith, 2011). These testing benefits are classified as direct and indirect effects. They include;

* its function as an aid to retrieval and later retention;

* its function of identifying gaps in knowledge; 
* Causing students to learn more from the next study episode;

* Producing better organization of knowledge;

* Improving transfer of knowledge to new context;

* Facilitating retrieval of material that was not tested;

* Improving meta-cognitive monitoring

* Providing feedback to instructors;

* Encouraging students to study.

Therefore, one can apparently say that testing improves learning. Likewise, teaching generally affects testing and testing could also affect teaching, which is responsible for the learning process. This kind of relationship among teaching, testing, and learning Is called the "backwash effect" in the field of measurement and evaluation. According to Gates (1995), backwash effect is the influence that a test could have on the teaching and learning process. Given all these issues about testing, it cannot be denied that it is still recognized as a practical and valid way of assessing students' knowledge and understanding developed in the process of teaching. Considering the value given to testing in classroom up to international assessments, for whatever purpose it may have, it is worth exploring how it could actually improve or impede teaching and learning particularly in often tested areas such as mathematics. Hence the study was carried out to investigate how high-stakes West African Senior Secondary Certificate Mathematics Examination influenced the teachers' teaching practices and the prescribed curriculum in Nigeria.

Several studies have reported the effects of external testing on both teaching and learning practices. One of such reports from a research conducted by Smith and Rottenberg, (1991) stated that external examinations make teachers teach to the test and consequently narrow the curriculum. Besides, implementation of learning methods that are time consuming may be compromised by examinations. Teachers resort to the use of methods that enable them to cover the syllabus content in the shortest possible time so that their pupils will have more time to revise for the examination. Therefore, what transpires during lessons is not much learning but a form of drilling. As a result, communicative and interactive methodologies that cater for the development of skills in the psychomotor and affective domains are neglected. Teachers are more concerned with perfecting pupils' techniques of answering examination questions. Chinyani, H., Kadodo, M. Madugwe, L. and Mandiudza, L. (2013)

Luis J. Rodríguez-Muñiz, Patricia Díaz, Verónica Mier and Pedro Alonso (2010) examined the Washback Effect of University Entrance Exams in Applied Mathematics to Social Sciences in Andalusia from 2009-2014 using quantitative and qualitative method. Data from Pruebas de Acceso a la Universidad (PAU) examinations was also collected. The aim was to determine how this examination aligns with curriculum and how it produced Washback on curriculum and teachers' work. Also, the questionnaire about teachers' practices was administered to determine the effects of the examination on teaching methodology. Evaluation of major result shows that the examination produced unfairness on the official curriculum. 50\% of teachers confessed that, if PAU did not exist, their teaching would have embraced the curriculum and more than $70 \%$ of the teachers admitted that they gave more attention to questions that are usually asked in PAU, thereby neglecting some parts of the curriculum. This leads to narrowing of the curriculum, which is an element of negative Washback. By implication, students' learning depth was also limited. If the examination made teachers to do selective teaching, it will adversely affect students learning and learning depth. According to Madaus $\underline{(1988)}$,

If the test is specific to a more specialized curriculum area where higher level cognitive outcomes are the goal, for example, college preparatory physics, the examination will eventually narrow instruction and learning. Instruction will eventually focus only on those things measured by the tests. Indeed, this narrowing of the curriculum has been one of the enduring complaints leveled at external examinations used for the important functions of certifying the successful completion of elementary or secondary education, and admission to tertiary education or certain jobs (Madaus, 1988, p38). 


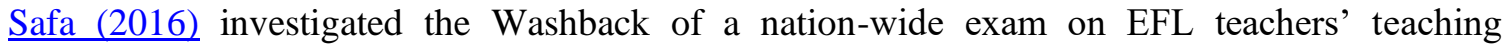
methodology on the educational system using a validated questionnaire administered to $160 \mathrm{EFL}$ teachers. The results indicated the final exam adversely affected EFL teachers' teaching methodology and increased teaching to the test practices as teachers taught according to the test's content and format. The results also showed stronger negative effect of the exam on EFL teachers' assessment procedures.

Tsagari D. (2011), explored the relationship between the intended influence of first certificate in English (FCE) examination, teachers perception towards the examination and teachers' classroom practices. It was discovered that the exam made students dependent on teachers concerning language learning and exams preparation. Students' dependence on teachers as well as their accountability towards parents and employers made teachers feel stressed and anxious as success in the exam was the yardstick for judging their professional status. Teachers focused on the topics and skills expected to be tested in the exams. Also, there was Washback in the way teachers designed their classroom test. They gave tests following the types found in the exam. The exam influenced learning leading to memorization of hundreds of prepositions, idiomatic expression, and others. In summary, the examination influenced both teachers and students negatively.

By implication, students who pass high-stakes examinations may not be academically good but may have passed due to the intense drilling they received on examination techniques and testwiseness. Such candidates may get the false impression that they are academically good and proceed to do advanced level studies. Through the same means, they get to university with good passes but very little understanding of basic concepts in particular subject areas and choose programs whose academic rigors may be heavy for them to handle. The chances of such students becoming incompetent professionals are very high. This is not true success and such individuals may not have any meaningful contribution to society in their areas of specialization. Consequently, there may not be evidence of positive impact of high stakes testing on students' performance.

According to Ruth M. (2006), emerging research is more rigorous about documenting practices that produce better test results than it is at describing the extent of "teaching to the test" in schools and classrooms. New research shows that teaching a curriculum aligned to state standards and using test data as feedback produces higher test scores than an instructional emphasis on memorization and test-taking skills. However, teaching to the test can be good or bad: Good if it means teaching a focused and aligned curriculum that enhances students' learning depth; bad if it encourages surface teaching/learning and reduce instruction to memorization of test items.

Asma A, Sabeen Q, and Isabel W. (2014) examined the Washback effects of the Pakistanian intermediate English examination on teaching, and the results indicated that teachers are teaching towards the examination. They focus on examination related activities to help students score better but research suggests that such practices may increase test scores without necessarily increasing understanding. Teachers tend to ignore speaking and listening in favour of reading and writing that are tested in the examination. The instructors felt that the examination restricted their teaching and so justified their negligence. Koretz, McCaffrey, and Hamilton (2003) identified seven teacher responses to high-stakes examinations. This includes providing more instructional time, working harder to cover more material, working more effectively, aligning instruction with standards, and cheating.

Furthermore, when high stakes are attached to performance, students tend to be less successful in acquiring higher-order and transferable skills. Thus, some of the basic education reform goals may be frustrated (Kellaghan, Madaus, and Raczek, 1996). Does standardized high-stakes tests really increase student capabilities and knowledge, or does it merely put more pressure on teachers and students, just to perform? Generally, high-stakes examination classroom teachers are faced with the problem of item teaching; teachers narrowly focus their instruction around a set of expected items (Popham, 2001). This practice, which is commonly referred to as "teaching to the test," provides little opportunity for in-depth and quality learning. Teachers use past examination papers for classroom instruction, and these past examination papers somehow define the curriculum. 'This contrasts the Constructivist theory of learning which stresses students' exposure to independent learning. In such an environment, learners build up their knowledge through deep thinking and manipulating relevant instructional materials and activities. Besides, the curriculum in the Constructivist setting describes the Mathematics teachers' responsibilities in four major areas: choosing or generating Mathematical 
tasks, inspiring and managing classroom discussion, making or creating a classroom learning environment and analyzing students learning. Mehmet 2005.

Furthermore, the Constructivist teacher does not focus on what is memorized but on what is understood and comprehended. This may not likely be achieved in a high-stake setting and educational system. However, there is need for empirical proof especially in Mathematics to verify what was intended in the Mathematics Curriculum, what was implemented, and what was achieved. Therefore, this research investigated the prescribed and implemented mathematics curriculum for the senior secondary exit class in Nigeria to ascertain discrepancies between the two if any, and also examined mathematics teachers' teaching practices/ teaching depth at the certificate class.

\section{Research methodology}

\section{Research Design}

The study adopted ex-post facto (non-experimental) design of a survey type. The investigatory survey was done without manipulating any of the variables used. In addition, an observation technique was employed to complement data from survey questionnaires and documentary analysis.

\section{Research Participants}

Simple random, stratified and purposive sampling techniques were used to select one thousand, seven hundred and nineteen (1719) senior secondary three (SS3) students and fifty-three (53) senior secondary three mathematics teachers from nine local government areas in Ebonyi state, Nigeria. However, ten out of the 53 teachers were purposively selected for classroom observation.

\section{Research Instruments}

Four research instruments were designed and validated for data collection and analysis

1. Depth of Teaching Rating Scale (DTRS)

2. Mathematics Content Completion Inventory (MCCI)

3. Mathematics Learning Task, (MLT)

4. Classroom Observation Checklist (COC)

\section{Depth of Teaching Rating Scale (DTRS)}

Depth of Teaching Rating Scale, (DTRS) was developed by the researcher based on experience as a Mathematics teacher and used to get information concerning Mathematics teaching depth. The instrument was made up of two columns; the first is an outline of detailed contents of the SS3 Curriculum for Mathematics. The researcher rated the teachers' teaching depth in relation to the Curriculum's contents in the second column. It is a modified Likert scale with response format; very good, good, poor, very poor and was scored 4, 3, 2 and 1 respectively. Teachers' lesson notes were reviewed vis-à-vis two randomly selected Mathematics notes of students and scored based on certain criteria.

\section{Mathematics Content Implementation Inventory (MCII).}

This is a self- report instrument developed by the researcher and contained items in the West African School Certificate Mathematics curriculum for the senior secondary school. The curriculum contents were clearly specified in the scale and teachers assessed themselves based on how contents of the curriculum were implemented in the class. This enabled the researcher to note aspects of the curriculum that are taught and the aspects neglected by the Senior Secondary School teachers in the participating schools. Response format is fully covered, partially covered and not attempted and was scored 3, 2 and 1 respectively. School diaries and student's mathematics notebooks were used to compare teachers' assessment of themselves. Mean scores from the three sources of information was calculated for each topic and used for the analysis. The instrument was face and content validated by two Senior Secondary Mathematics teachers from schools outside the sampled schools. This was done to ensure that contents of the Curriculum were stated without error or omission.

\section{Mathematics Learning Task (MLT).}

Mathematics Learning Task, (MLT) is a validated 13 Essay item Mathematics task, used to elicit information concerning the influence of the examination on the depth of students leaning. The Essay 
type task was chosen to enable the researcher to measure students' cognitive ability in the various topics outlined in the senior secondary school Curriculum. Completing an assigned task will enable the researcher to evaluate students' depth of learning. The items were adopted from the 2012, 2013, 2014, 2015 and 2016 West African Senior Secondary Certificate Mathematics Examination questions and were scored using the WAEC analytical method of grading. The marking scheme used for the questions were those prepared by WAEC for these years. Inter-rater reliability was computed and found to be 0.953 .

\section{Classroom Observation Checklist (COC)}

Classroom Observation Checklist is an observational instrument used to observe and check Mathematics classroom teaching and learning activities and interactions as depicted in a typical certificate class. This instrument was divided into two parts. The first part consists of pre-determined behaviours and activities in typical SS3 classes, which are meant to be observed. The other part represents the timing. This part had 40 cells which represents the duration for a period lesson in secondary schools. Observation was made every minute and the observer categorized the observed activity and recorded them in the sequence of occurrence and time during which the behaviour occurred. This helped the researcher to identify activities that dominate the West African Senior Secondary Certificate Mathematics classroom. This instrument was trial tested by the researcher and a research assistant on a Mathematics teacher for a 40 minutes Mathematics lesson. The inter-rater reliability procedure was used to establish the instrument's reliability, which was estimated to be 0.989 .

\section{Research Procedure}

Data collection lasted for twelve weeks and was carried out in phases. Phase one was used for training of research assistants and trial testing of research instruments. Phase two was used for class observation, while phase three was utilized to administer questionnaires to teachers, administration of Mathematics Learning Task, (MLT) to students, and documentary analysis. Data were analyzed using appropriate descriptive statistical models in SPSS version 20.

\section{Results and discussions}

Research Question 1 What level of discrepancies exist between the Senior Secondary Certificate Mathematics Curriculum content in Nigeria and what teachers teach?

Table 1 below outlines the mathematics curriculum contents and presents a summary of descriptive statistics of curriculum implementation level among Mathematics teachers. By inspection of the statistics displayed, the majority of the teachers implemented the prescribed curriculum. However, differentiation of algebraic fractions and Construction was Poorly taught. The table also noted that, for every topic outlined in the table above, there were teachers who never attempted teaching them. For example, 8 out of the investigated teachers did not attempt logical reasoning and construction, 6 teachers never attempted teaching differentiation and integration, Histograms of grouped data, Cumulative frequency graph, Proofs of some fundamental theorems, Trigonometric ratios/graphs, Matrices and Determinants. An overall assessment of the table indicates that an average of 66 percent of the Mathematics teachers fully implemented the prescribed curriculum leaving 34 percent for partial implementation and not attempted.

Table 1

Mathematics Content Implementation Inventory (MCII)

\begin{tabular}{|l|l|l|l|l|l|l|}
\hline \multirow{2}{*}{ Topics } & \multicolumn{2}{|l|}{ Not attempted } & \multicolumn{2}{l|}{$\begin{array}{l}\text { Partially } \\
\text { completed }\end{array}$} & \multicolumn{2}{l|}{$\begin{array}{l}\text { Fully } \\
\text { completed }\end{array}$} \\
\cline { 2 - 8 } & Num. & $\%$ & Num. & $\%$ & Num. & $\%$ \\
\hline Number base system & 4 & 7.7 & 5 & 9.6 & 43 & 83.7 \\
\hline Modular arithmetic & 5 & 9.6 & 13 & 25.0 & 34 & 65.4 \\
\hline Indices and standard form & 4 & 7.7 & 3 & 5.8 & 45 & 86.5 \\
\hline Logarithms & 4 & 7.7 & 4 & 7.7 & 44 & 84.6 \\
\hline
\end{tabular}




\begin{tabular}{|l|l|l|l|l|l|l|}
\hline Sets & 4 & 7.7 & 6 & 11.5 & 42 & 80.8 \\
\hline Simple equation and variation & 4 & 7.7 & 6 & 11.5 & 42 & 80.8 \\
\hline Quadratic equations/graphs & 4 & 7.7 & 6 & 11.5 & 42 & 80.8 \\
\hline Logical reasoning & 8 & 15.4 & 16 & 30.8 & 28 & 53.8 \\
\hline Constructions & 8 & 15.4 & 20 & 38.5 & 24 & 46.2 \\
\hline Proofs of some basic theorems & 6 & 11.5 & 18 & 34.6 & 28 & 52.8 \\
\hline Trigonometric ratios/graphs & 6 & 11.5 & 14 & $26 . .9$ & 32 & 61.5 \\
\hline Mensuration & 5 & 9.6 & 13 & 25.0 & 34 & 65.4 \\
\hline Statistics (data presentation) & 5 & 9.6 & 12 & 23.1 & 35 & 67.3 \\
\hline Sequences and series & 4 & 7.7 & 9 & 17.3 & 39 & 75.0 \\
\hline $\begin{array}{l}\text { Simultaneous linear and quadratic } \\
\text { equations }\end{array}$ & 4 & 7.7 & 9 & 17.3 & 39 & 75.0 \\
\hline Gradient of a curve & 5 & 9.6 & 13 & 25.0 & 34 & 65.4 \\
\hline Linear inequalities & 5 & 9.6 & 12 & 23.1 & 35 & 67.3 \\
\hline Algebraic fractions & 5 & 9.6 & 11 & 21.2 & 36 & 69.2 \\
\hline Chord property & 5 & 9.6 & 12 & 23.1 & 35 & 67.3 \\
\hline Circle theorems & 4 & 7.7 & 14 & 26.9 & 34 & 65.4 \\
\hline Bearings & 4 & 7.7 & 14 & 26.9 & 34 & 65.4 \\
\hline Measures of central tendency & 4 & 7.7 & 11 & 21.2 & 37 & 71.2 \\
\hline Measures of dispersion & 5 & 9.6 & 14 & 26.9 & 33 & 63.5 \\
\hline Histograms of grouped data & 6 & 11.5 & 9 & 17.0 & 37 & 69.8 \\
\hline Cumulative frequency graph & 6 & 11.5 & 12 & 23.1 & 34 & 65.4 \\
\hline $\begin{array}{l}\text { Measures of central tendency for } \\
\text { grouped data }\end{array}$ & 5 & 9.6 & 13 & 25.0 & 34 & 65.4 \\
\hline Probability & 5 & 9.6 & 14 & 26.9 & 33 & 63.5 \\
\hline Surds & 4 & 7.7 & 11 & 21.2 & 37 & 71.2 \\
\hline Matrices and determinants & 6 & 11.5 & 16 & 30.2 & 30 & 57.7 \\
\hline Arithmetic of finance & 5 & 9.6 & 18 & 34.6 & 29 & 55.8 \\
\hline $\begin{array}{l}\text { Application of linear and quadratic } \\
\text { equations to capital market }\end{array}$ & 3 & 5.8 & 18 & 34.6 & 31 & 59.6 \\
\hline Surface area and volume of sphere & 3 & 5.8 & 17 & 32.7 & 32 & 61.5 \\
\hline Longitude and latitude & 4 & 7.7 & 14 & 26.9 & 34 & 65.4 \\
\hline $\begin{array}{l}\text { Coordinate geometry of straight } \\
\text { lines }\end{array}$ & 3 & 5.8 & 24 & 46.2 & 25 & 48.1 \\
\hline $\begin{array}{l}\text { Differentiation of algebraic } \\
\text { fractions }\end{array}$ & 6 & 11.5 & 22 & 42.3 & 24 & 46.2 \\
\hline & & $\approx 9$ & & $\approx 24$ & & $\approx 66$ \\
\hline
\end{tabular}

\section{Discussion of Findings to Research Question 1}

This section sought to find out if there were discrepancies between the prescribed curriculum and implemented curriculum. The aim was to find out differences between teaching content and curriculum content. Findings reveal that, to a large extent, teachers fully implemented curriculum content in the instructional process. Full implementation ranged between $46.2 \%$ and $86.5 \%$ for different topics. However, some topics need special attention. Such topics include; Differentiation of algebraic fractions, Coordinate geometry of straight lines, construction, Matrices and determinants, Arithmetic of finance and Application of linear and quadratic equations to capital market. This is probably because some of these topics were newly introduced into the curriculum and most teachers are incompetent to handle them.

Again, construction was poorly taught as evidenced on the table, reflecting only $46 \%$ of full implementation. This may be due to lack of instructional materials like compass, protractor and meter rule or even lack of competence among teachers in material usage. This topic is purely practical and demands special skills. Results from class observation showed that among nine categories of 
classroom practices observed, the use of instructional materials had the least score with only 6 observed occurrences out of 4000 and a percentage value of 0.15 .

To conclude, the discrepancy between teaching content and curriculum content as discovered in this research is not significant since an aggregate average of sixty-six (66) percent of the teachers fully implemented curriculum contents. This is above the mean percent of fifty. That notwithstanding, the recently introduced topics, as well as construction and coordinate geometry, were reported to be minimally implemented.

Research Question 2: What kind of teaching practices dominates the Senior Secondary Certificate Mathematics class?

An overview of table 2 and 3 below indicates that classroom teaching activities revolves around examination preparation with the highest percentage of 48.55 among nine different categories. By implication, $48.55 \%$ of class time was used for examination practice tests. This figure represents almost half of the instructional time. Activities that characterized this category include: Students practicing multiple choice, Students practicing essay type, Teacher solving multiple choice, Teacher solving essay type, Teacher aiding students to memorize formula and Teacher training students on specific question type. This was followed by lecturing or instructing (teacher centred) with a percentage of 15.9. Next is active learning (Discovery learning and Learning by doing it on the board - learner-centered), which accounts for $12.35 \%$, followed by assessment practices (Class work, Test or quiz, Teacher checking homework and teacher Correcting homework) with a percentage of 9.95.

Table 2

Summary of Observational Data across schools

\begin{tabular}{|l|c|c|c|c|c|c|c|c|c|c|c|}
\hline $\begin{array}{l}\text { CATEGORIES } \\
\text { OF } \\
\text { CLASSROOM } \\
\text { PRACTICES }\end{array}$ & $\mathbf{1}$ & $\begin{array}{c}\text { SCH } \\
\mathbf{2}\end{array}$ & $\begin{array}{c}\text { SCH } \\
\mathbf{3}\end{array}$ & $\begin{array}{c}\text { SCH } \\
\mathbf{4}\end{array}$ & $\begin{array}{c}\text { SCH } \\
\mathbf{5}\end{array}$ & $\begin{array}{c}\text { SCH } \\
\mathbf{6}\end{array}$ & $\begin{array}{c}\text { SCH } \\
\mathbf{7}\end{array}$ & $\begin{array}{c}\text { SCH } \\
\mathbf{8}\end{array}$ & $\begin{array}{c}\text { SCH } \\
\mathbf{9}\end{array}$ & $\begin{array}{c}\text { SCH } \\
\mathbf{1 0}\end{array}$ & $\begin{array}{l}\text { GRAND } \\
\text { TOTAL }\end{array}$ \\
\hline $\begin{array}{l}\text { (A).Examination } \\
\text { preparatory } \\
\text { activities }\end{array}$ & 80 & 155 & 276 & 103 & 189 & 213 & 241 & 273 & 238 & 174 & 1942 \\
\hline $\begin{array}{l}\text { (B). Active } \\
\text { learning } \\
\text { practices }\end{array}$ & 35 & 26 & 14 & 199 & 20 & 43 & 50 & 38 & 42 & 27 & 494 \\
\hline $\begin{array}{l}\text { (C).Assessment } \\
\text { practices }\end{array}$ & 67 & 85 & 38 & 73 & 37 & 28 & 10 & 19 & 25 & 16 & 398 \\
$\begin{array}{l}\text { (D).Teaching test } \\
\text { taking } \\
\text { techniques }\end{array}$ & 8 & 48 & 13 & 17 & 8 & 14 & 14 & 11 & 16 & 15 & 164 \\
\hline $\begin{array}{l}\text { (E).Instructional } \\
\text { materials }\end{array}$ & 0 & 0 & 1 & 0 & 0 & 0 & 2 & 0 & 0 & 3 & 6 \\
\hline $\begin{array}{l}\text { (F).Lecturing or } \\
\text { Instructing }\end{array}$ & 157 & 32 & 26 & 0 & 104 & 66 & 55 & 19 & 40 & 137 & 636 \\
\hline (G).Dialogue & 25 & 43 & 13 & 5 & 31 & 14 & 14 & 18 & 20 & 10 & 193 \\
\hline $\begin{array}{l}\text { (H).Laughter/hu } \\
\text { mor }\end{array}$ & 8 & 5 & 9 & 1 & 4 & 5 & 3 & 12 & 9 & 5 & 61 \\
\hline (I).Others & 20 & 6 & 10 & 2 & 7 & 17 & 11 & 10 & 10 & 13 & 106 \\
\hline & 400 & 400 & 400 & 400 & 400 & 400 & 400 & 400 & 400 & 400 & 4000 \\
\hline
\end{tabular}


Table 3:

Summary of Observational Data

\begin{tabular}{|l|c|c|}
\hline \multicolumn{1}{|c|}{ Categories } & $\begin{array}{c}\text { Number of } \\
\text { occurrences }\end{array}$ & Percentages \\
\hline Examination preparatory activities & 1942 & $48.55 \%$ \\
\hline Active learning practices & 494 & $12.35 \%$ \\
\hline Assessment practices & 398 & $9.95 \%$ \\
\hline Teaching test taking techniques & 164 & $4.1 \%$ \\
\hline Instructional Materials & 6 & $0.15 \%$ \\
\hline $\begin{array}{l}\text { Lecturing or } \\
\text { Instructing }\end{array}$ & 636 & $15.9 \%$ \\
\hline Dialogue & 193 & $4.825 \%$ \\
\hline Laughter/humour & 61 & $1.525 \%$ \\
\hline Others & 106 & $2.65 \%$ \\
\hline Total & $\mathbf{4 0 0 0}$ & $\mathbf{1 0 0 \%}$ \\
\hline
\end{tabular}

\section{Percentage of Categories}

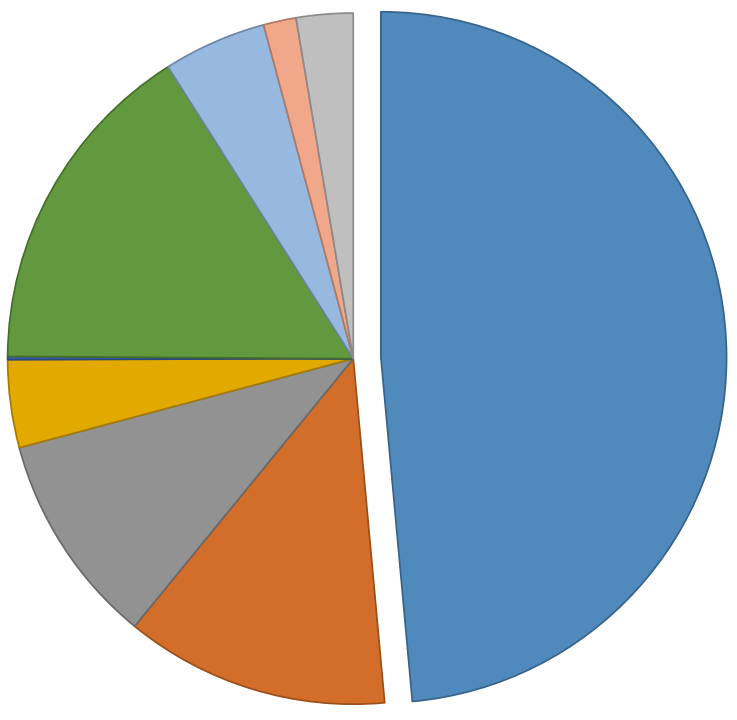

$\square$ Exam Prep

$\square$ active learning

Assessment

$\square$ Testing Technigues

$\square$ Instructional

$\square$ Lecturing

$\square$ Dialogue

$\square$ Laughter

$\square$ Others

Figure1: Pie Chart representing Observation Data Summary

\section{Discussion of findings to Research Question two}

Major finding from this section is the influence of the examination on teaching strategies employed by teachers. Results show that majority of the teachers adopted teaching to the test and past question strategies in the instructional process confirming one of Wall and Alderson's 1993 Washback hypothesis ( a test will influence what teachers teach) and also supporting the findings of (Madaus 1988; Tsagari 2011; Amengual 2010 and 2013; Shiva 2012). This is a negative effect of the examination because it restricts teaching methodology and encourages surface teaching and learning which according to Asma A, Sabeen Q, and Isabel W. (2014) may lead to increase in test scores without a commensurate increase in understanding. Besides, these strategies cannot guarantee long term learning of Mathematical concepts and therefore do not reflect a permanent change in the learner's characteristics in the Mathematical domain. Thus there will no retention and transfer of knowledge as evidenced by low scores in the Mathematics learning task administered to students. 
Research Question 3. What is the depth of Mathematics teaching at the certificate exit class?

Teaching depth rating scale earlier described was used to measure the depth of teaching carried out by the mathematics teachers involved in this research. Table 4 presents the mean teaching depth of the senior secondary mathematics curriculum contents by fifty-three mathematics teachers.

Table 4:

Mathematics Teaching Depth Analysis

\begin{tabular}{|c|c|c|c|c|c|c|c|}
\hline $\mathrm{S} / \mathrm{N}$ & TOPICS & $\mathrm{N}$ & $\begin{array}{l}\text { MINIM } \\
\text { UM } \\
\text { SCORE }\end{array}$ & $\begin{array}{l}\text { MAXIM } \\
\text { UM } \\
\text { SCORE }\end{array}$ & MEAN & $\begin{array}{l}\text { MEAN } \\
\text { BENCH } \\
\text { MARK }\end{array}$ & DECISION \\
\hline 1. & Define differentiation & 53 & 1.00 & 4.00 & 2.0566 & 3 & NIT \\
\hline 2. & $\begin{array}{l}\text { Explain the meaning of a } \\
\text { derived function }\end{array}$ & 53 & 1.00 & 4.00 & 1.9623 & 3 & NIT \\
\hline 3. & $\begin{array}{l}\text { Perform differentiation } \\
\text { from first principles }\end{array}$ & 53 & 1.00 & 4.00 & 1.6604 & 3 & NIT \\
\hline 4. & $\begin{array}{l}\text { Standard derivatives of } \\
\text { some basic functions }\end{array}$ & 53 & 1.00 & 3.00 & 1.6604 & 3 & NIT \\
\hline 5. & $\begin{array}{l}\text { Rules of differentiation to } \\
\text { solve related problems }\end{array}$ & 53 & 1.00 & 4.00 & 1.6415 & 3 & NIT \\
\hline 6. & $\begin{array}{l}\text { Application of } \\
\text { differentiation to real life } \\
\text { such as maxima and } \\
\text { minima, velocity, } \\
\text { acceleration and capital } \\
\text { market issues }\end{array}$ & 53 & 1.00 & 4.00 & 1.4528 & 3 & NIT \\
\hline 7. & $\begin{array}{l}\text { Plot linear graph in the } x-y \\
\text { plane }\end{array}$ & 53 & 1.00 & 4.00 & 2.2075 & 3 & NIT \\
\hline 8. & $\begin{array}{l}\text { Rational and irrational } \\
\text { numbers }\end{array}$ & 53 & 1.00 & 4.00 & 3.3208 & 3 & IT \\
\hline 9. & $\begin{array}{l}\text { Addition, subtraction, } \\
\text { multiplication and division } \\
\text { of surds }\end{array}$ & 53 & 1.00 & 4.00 & 3.0943 & 3 & IT \\
\hline 10. & Conjugate binomial surds & 53 & 1.00 & 4.00 & 3.1698 & 3 & IT \\
\hline 11. & $\begin{array}{l}\text { Application of surds to } \\
\text { trigonometric ratios }\end{array}$ & 53 & 1.00 & 4.00 & 2.9623 & 3 & NIT \\
\hline 12. & $\begin{array}{l}\text { Definition, order and } \\
\text { notation of a matrix }\end{array}$ & 53 & 1.00 & 4.00 & 2.7736 & 3 & NIT \\
\hline 13. & Types of Matrices & 53 & 1.00 & 4.00 & 2.8868 & 3 & NIT \\
\hline 14. & $\begin{array}{l}\text { Addition and subtraction of } \\
\text { Matrices }\end{array}$ & 53 & 1.00 & 4.00 & 2.7358 & 3 & NIT \\
\hline 15. & $\begin{array}{l}\text { Multiplication of a matrix } \\
\text { by a scalar quantity }\end{array}$ & 53 & 1.00 & 4.00 & 2.7170 & 3 & NIT \\
\hline 16. & $\begin{array}{l}\text { Multiplication of a matrix } \\
\text { by another matrix }\end{array}$ & 53 & 1.00 & 4.00 & 2.5849 & 3 & NIT \\
\hline 17. & $\begin{array}{l}\text { Finding the transpose of a } \\
\text { matrix }\end{array}$ & 53 & 1.00 & 4.00 & 2.6038 & 3 & NIT \\
\hline 18. & Calculating the & 53 & 1.00 & 4.00 & 2.3774 & & NIT \\
\hline
\end{tabular}




\begin{tabular}{|c|c|c|c|c|c|c|c|}
\hline & $\begin{array}{l}\text { determinants of a } 2 \times 2 \\
\text { matrix }\end{array}$ & & & & & 3 & \\
\hline 19. & $\begin{array}{l}\text { Applying matrices to } \\
\text { solving simultaneous } \\
\text { equations }\end{array}$ & 53 & 1.00 & 4.00 & 2.3962 & 3 & NIT \\
\hline 20. & Deduce laws of logarithms & 53 & 1.00 & 4.00 & 2.5283 & 3 & NIT \\
\hline 21. & $\begin{array}{l}\text { Verification of logarithm } \\
\text { laws with simple exercises }\end{array}$ & 53 & 1.00 & 4.00 & 2.6604 & 3 & NIT \\
\hline 22. & $\begin{array}{l}\text { Solve problems involving } \\
\text { calculations with logarithm } \\
\text { tables }\end{array}$ & 53 & 1.00 & 4.00 & 2.8679 & 3 & NIT \\
\hline 23. & $\begin{array}{l}\text { Use formula to solve } \\
\text { problems involving simple } \\
\text { interest }\end{array}$ & 53 & 1.00 & 4.00 & 2.5094 & 3 & NIT \\
\hline 24. & $\begin{array}{l}\text { Use formula to solve } \\
\text { problems on compound } \\
\text { interest }\end{array}$ & 53 & 1.00 & 4.00 & 2.5094 & 3 & NIT \\
\hline 25. & $\begin{array}{l}\text { Compute the depreciation } \\
\text { value of an item }\end{array}$ & 53 & 1.00 & 4.00 & 2.5094 & 3 & NIT \\
\hline 26. & $\begin{array}{l}\text { Compute the annuities of a } \\
\text { given problem }\end{array}$ & 53 & 1.00 & 4.00 & 2.3208 & 3 & NIT \\
\hline 27. & $\begin{array}{l}\text { Calculate compound } \\
\text { interest using logarithm } \\
\text { table }\end{array}$ & 53 & 1.00 & 4.00 & 2.2075 & 3 & NIT \\
\hline 28. & $\begin{array}{l}\text { Calculate interest on bonds } \\
\text { and debentures using } \\
\text { logarithm table }\end{array}$ & 53 & 1.00 & 4.00 & 2.2075 & 3 & NIT \\
\hline 29. & $\begin{array}{l}\text { Solve problems on taxes, } \\
\text { rates and value added tax } \\
\text { (VAT) }\end{array}$ & 53 & 1.00 & 4.00 & 2.4151 & 3 & NIT \\
\hline 30. & $\begin{array}{l}\text { Solve problems on } \\
\text { simultaneous linear and } \\
\text { quadratic equations }\end{array}$ & 53 & 1.00 & 4.00 & 2.3396 & 3 & NIT \\
\hline 31. & $\begin{array}{l}\text { Solve word problems on } \\
\text { simultaneous linear } \\
\text { equations, quadratic } \\
\text { equations, one linear and } \\
\text { one quadratic equations }\end{array}$ & 53 & 1.00 & 4.00 & 2.5472 & 3 & NIT \\
\hline 32. & $\begin{array}{l}\text { Solve problems on linear } \\
\text { equations involving capital } \\
\text { market }\end{array}$ & 53 & 1.00 & 4.00 & 2.2830 & 3 & NIT \\
\hline 33. & $\begin{array}{l}\text { Construct various tables of } \\
\text { values of sine and cosine }\end{array}$ & 53 & 1.00 & 4.00 & 2.1321 & 3 & NIT \\
\hline 34. & $\begin{array}{l}\text { Plot graph of sine and } \\
\text { cosine using the } \\
\text { constructed table for } 0 ? \times \text { ? } \\
360\end{array}$ & 53 & 1.00 & 4.00 & 2.2075 & 3 & NIT \\
\hline 35. & $\begin{array}{l}\text { Interpret the plotted graph } \\
\text { and read out given values }\end{array}$ & 53 & 1.00 & 4.00 & 2.3208 & 3 & NIT \\
\hline 36. & $\begin{array}{l}\text { Graphical solutions to } \\
\text { simultaneous linear and } \\
\text { trigonometric equations }\end{array}$ & 53 & 1.00 & 4.00 & 2.3962 & 3 & NIT \\
\hline 37. & Characteristics of a sphere & 53 & 1.00 & 4.00 & 2.3774 & & NIT \\
\hline
\end{tabular}




\begin{tabular}{|c|c|c|c|c|c|c|c|}
\hline & & & & & & 3 & \\
\hline 38. & Concept of surface area & 53 & 1.00 & 4.00 & 2.3396 & 3 & NIT \\
\hline 39. & $\begin{array}{l}\text { Finding and solving } \\
\text { problems on the surface } \\
\text { area of a sphere }\end{array}$ & 53 & 1.00 & 4.00 & 2.6038 & 3 & NIT \\
\hline 40. & $\begin{array}{l}\text { Finding the volume of a } \\
\text { sphere practically }\end{array}$ & 53 & 1.00 & 4.00 & 2.4906 & 3 & NIT \\
\hline 41. & $\begin{array}{l}\text { Finding the volume of a } \\
\text { sphere by formula }\end{array}$ & 53 & 1.00 & 4.00 & 2.4906 & 3 & NIT \\
\hline 42. & $\begin{array}{l}\text { Solve problems on the } \\
\text { volume of spheres }\end{array}$ & 53 & 1.00 & 4.00 & 2.1509 & 3 & NIT \\
\hline 43. & $\begin{array}{l}\text { Description of the earth as } \\
\text { a sphere }\end{array}$ & 53 & 1.00 & 4.00 & 2.3585 & 3 & NIT \\
\hline 44. & $\begin{array}{l}\text { Identifying, appreciating } \\
\text { and locating(using a } \\
\text { skeletal globe), the } \\
\text { different parts of the earth } \\
\text { e.g, north and south poles, } \\
\text { longitude, latitude equator } \\
\text { etc }\end{array}$ & 53 & 1.00 & 4.00 & 2.4340 & 3 & NIT \\
\hline 45. & $\begin{array}{l}\text { Solving problems on the } \\
\text { length of an arc of a circle }\end{array}$ & 53 & 1.00 & 4.00 & 2.4717 & 3 & NIT \\
\hline 46. & $\begin{array}{l}\text { Solving problems on } \\
\text { longitude and latitude }\end{array}$ & 53 & 1.00 & 4.00 & 2.4528 & 3 & NIT \\
\hline 47. & $\begin{array}{l}\text { Locate position of a point } \\
\text { in a coordinate system }\end{array}$ & 53 & 1.00 & 4.00 & 2.1887 & 3 & NIT \\
\hline 48. & $\begin{array}{l}\text { Determine the distance } \\
\text { between two coordinate } \\
\text { points }\end{array}$ & 53 & 1.00 & 4.00 & 2.1509 & 3 & NIT \\
\hline 49. & $\begin{array}{l}\text { Determine the midpoint of } \\
\text { a line }\end{array}$ & 53 & 1.00 & 4.00 & 2.0377 & 3 & NIT \\
\hline 50. & $\begin{array}{l}\text { Apply coordinate geometry } \\
\text { to everyday life situations }\end{array}$ & 53 & 1.00 & 4.00 & 2.0000 & 3 & NIT \\
\hline 51. & $\begin{array}{l}\text { Define and determine the } \\
\text { gradient and intercept of a } \\
\text { line }\end{array}$ & 53 & 1.00 & 4.00 & 2.2830 & 3 & NIT \\
\hline 52. & $\begin{array}{l}\text { Determine the equation of a } \\
\text { line }\end{array}$ & 53 & 1.00 & 4.00 & 2.0943 & 3 & NIT \\
\hline 53. & $\begin{array}{l}\text { Calculate the angles } \\
\text { between two lines }\end{array}$ & 53 & 1.00 & 4.00 & 2.0943 & 3 & NIT \\
\hline 54. & $\begin{array}{l}\text { Applying linear graph to } \\
\text { real life situation }\end{array}$ & 53 & 1.00 & 4.00 & 2.1132 & 3 & NIT \\
\hline
\end{tabular}

NIT- NOT INDEPTHLY TAUGHT

IT- INDEPTHLY TAUGHT

With a benchmark of $3.0(75 \%)$ rating considered in-depth, it is observed that only three out of fifty-four topics were given in-depth teaching. This value represents only $5.66 \%$ of the topics, which is far below expectation.

\section{Conclusion}

This study investigated the prescribed and implemented Mathematics curriculum of the West African Senior Secondary examination. Based on the study's findings, it can be concluded that high-stakes West African Senior Secondary Certificate Mathematics examination distorts the teaching process by restricting teachers from using active teaching methods in instructional delivery. This is a 
significant negative effect of the examination. Besides, the examination encouraged teaching to the test and performance goal orientation. Teaching activities typical of the certificate class cannot guarantee in-depth Mathematics knowledge or significant achievement gain, as $28.08 \%$ was calculated to be the mean score of students' in the Mathematics learning task administered to them at the peak of their preparation the WASSCE.

\section{Recommendation}

a) Credit passes in Mathematics, for university admission, should only be made compulsory for the sciences, social sciences, and management sciences. This will help reduce the stakes on the subject and consequently minimize unhealthy teaching practices.

b) The Government and private school administrators should provide a well-equipped and usable Mathematics laboratory in their various schools to reduce mathematical abstraction and enhance learners' understanding of mathematical concepts..

c) The Education Board, Ministry and State Government should organize a comprehensive and intensive in-service training for teachers to actualize effective implementation of the newly included topics in the Mathematics Curriculum.

d) Mathematics teachers of the exit secondary class (SS3) should adopt more active teaching strategies that will lead to in-depth mathematical knowledge. Focus should be on quality teaching rather than quantity.

e) The Mathematics teachers should dutifully follow the prescribed curriculum in the instructional process to understand topical concepts, logic and application. This will enhance mathematical knowledge depth.

\section{References}

Alderson and Wall. (1993). Does washback exist?. Applied Linguistics, 14(2), 115-129.

Amengual, P. (2009). Does the English test in the Spanish university entrance examination influence the teaching of English?, English studies, 90(5), 582-598.

Asma, A., Sabeen, Q, and Isabel, W. (2014). Investigating the washback effect of the Pakistani intermediate English examination. International Journal of English and Literature, 5(7), 149-154. https://doi.org/10.5897/IJEL2013.052.

Azuka, B., Jekayinfa, O., Durojaiye, D., \& Okwuoza, S. (2013). Difficulty levels of topics in the new senior secondary school mathematics curriculum as perceived by mathematics teachers of Federal Unity Schools in Nigeria. Journal of Education and Practice, 4(17), 23-29.

Chinyani, H., Kadodo, M. Madugwe, L. and Mandiudza, L. (2013). The impact of Examination on School Curriculum: A Zimbabwean Perspective. Internatonal Journal in Progressive Education and Development, 2(1).

Enwefa, C. (2014). Teachers perception of washback effect of high-stakes tests on post university tertiary matriculation examination in Delta State University Abraka.

Gates, S. (1995). Exploiting Washback from standardized tests. In J. D. Brown, and S. Yamashita (Eds.), Language testing in Japan (pp. 101-106). Tokyo: Japanese Association for Language Teaching.

Kelleghan, T., Madaus, G. F. and Raczek, A. (1996). The use of external examinations to improve student motivation, Washington DC, AERA.

Koretz, D. M., Mc.Caffrey, J. R., Lockwood, D. F. and Hamilton, L. S. (2003). Evaluating value added models for teacher accountability [Monograph]. Santa Monica, CA: RAND Corporation. http://www.rand.org/pubs/monographs/2004/RAND_MG158.pdf.

Kulamakan K. and Patangi K. (2018). Beyond "formative": assessments to enrich student learning. Retrieved from https://doi.org/10.1152/advan.00122.2017.

Linn, R. (2000). Assessment and accountability. Educational Researcher, 29, 4-16.

Luis J. Rodríguez-Muñiz, Patricia Díaz, Verónica Mier, and Pedro Alonso. (2016). Washback effect of university entrance exams in applied mathematics to social science PLos One. 2016; 11(12): $\mathrm{e} 0167544$.

Madaus, G.F. (1988). The influence of testing on the curriculum. In Tanner, L.N., editor, Critical issues in curriculum: eighty-seventh yearbook of the National Society for the Study of Education (Part 1). Chicago: University of Chicago Press. 
Mehmet. (2005). Fundamental of research methodology. London, United Kingdom: Paraclete Publisher.

Popham, W. J. (1999). Why standardized tests don't measure educational quality. Educational Leadership, 56(6).

Roediger, H.L., Putnam, A.L. \& Smith, M.A (2011). Ten benefits of testing and their applications to educational practice. Psychology of Learning and Motivation, 55. Elsevier, Inc.

Ruth M, (2006). High-stakes testing and effects on instructions: Research review.

Sabio, J., Balagtas, M., \& David, D. (2015). "Backwash Effects" of testing on learning mathematics. The Normal Lights, 9(2), $156-179$.

Safa, A.M., (2016). The Washback effects of high school third grade exam on EFL Teachers' Methodology, Evaluation and Attitude. Applied Research in English 5(1)

Saye John (2013), Theory and research in social education. Social Studies Enquiry Research Collaborative (SSIRC), 41(1), 89-132.

Shiva, E. (2012). A comparative Washback study of IELTS and TOEFL IBT on teaching and learning activities in preparation courses in the Iranian Context. Journal of English language teaching, vol.15, No. 8.

Smith M.L. and Rottenberg C. (1991). Unintended consequences of external testing in elementary schools. Educational Measurement: Issues and Practice, 10(4),7-11.

Tsagari, D. (2011). Washback of a high-stakes English Examination on teachers' perceptions and practices. Selected papers from the 19th ISTAL, 431-445.

Tugba, A. (2012). An exploration of the effects of High-stakes examinations on the teaching and learning of mathematics in post primary education in Ireland and Turkey. Published Ph.D thesis, University of Ireland, Maynooth.

UNESCO Science Report. (2015). Education 2030: towards inclusive and equitable quality education and lifelong learning for all. Pari: UNESCO 